\title{
Effect of Media with Different Glycerol Concentrations on Sheep Red Blood Cells' Viability In Vitro
}

\author{
Valeria Pasciu *(D), Francesca D. Sotgiu (D), Cristian Porcu (D) and Fiammetta Berlinguer (D) \\ Department of Veterinary Medicine, University of Sassari, 07100 Sassari, Italy; fran.sotgiu@gmail.com (F.D.S.); \\ cporcu@uniss.it (C.P.); berling@uniss.it (F.B.) \\ * Correspondence: vpasciu@uniss.it
}

check for updates

Citation: Pasciu, V.; Sotgiu, F.D.; Porcu, C.; Berlinguer, F. Effect of Media with Different Glycerol Concentrations on Sheep Red Blood Cells' Viability In Vitro. Animals 2021, 11, 1592. https://doi.org/10.3390/ ani11061592

Academic Editor: Paul Mozdziak

Received: 26 March 2021

Accepted: 27 May 2021

Published: 28 May 2021

Publisher's Note: MDPI stays neutral with regard to jurisdictional claims in published maps and institutional affiliations.

Copyright: (c) 2021 by the authors. Licensee MDPI, Basel, Switzerland. This article is an open access article distributed under the terms and conditions of the Creative Commons Attribution (CC BY) license (https:// creativecommons.org/licenses/by/ $4.0 /)$.
Simple Summary: Glycerol is widely used as a feed supplement in ruminant nutrition. However, its administration at moderate and high doses results in an increase in plasma osmolality and in an alteration of red blood cell (RBC) indices. The present study aimed at further elucidating the effect of glycerol on RBCs' functionality by evaluating the effect of different glycerol concentrations on RBC homeostasis under in vitro conditions. Obtained results showed that glycerol permeates the RBC membrane and leads to hemolysis when glycerol concentration exceeds $200 \mathrm{mg} / \mathrm{dL}$. However, RBCs' antioxidant defenses appear to protect cell membranes without causing an increase of oxidative stress markers. Moreover, no alteration in $\mathrm{RBCs}^{\prime}$ intracellular $\mathrm{Ca}^{2+}$ ion concentrations and metabolic activity were found. In conclusion, glycerol-based nutritional treatment should be designed in sheep to avoid exceeding $200 \mathrm{mg} / \mathrm{dL}$ glycerol circulating concentration to prevent RBC osmotic stress.

Abstract: The use of high doses of glycerol as a livestock feed supplement is followed by a rapid increase in plasma concentrations and consequently in plasma osmolality. Moreover, glycerol is a highly diffusible molecule that can readily permeate the red blood cell (RBC) membrane following a concentration gradient. A rise in glycerol plasma concentrations can thus alter RBC homeostasis. The present study aimed at investigating both glycerol osmotic effects on sheep RBCs and their oxidative response under in vitro conditions. Sheep blood samples were suspended in media supplemented with increasing glycerol concentrations $(0,25,50,100,150,200,250,300,350,400 \mathrm{mg} / \mathrm{dL})$, which reflected those found in vivo in previous studies, and incubated at $37^{\circ} \mathrm{C}$ for $4 \mathrm{~h}$. Thereafter, osmolality and hemolysis were determined in spent media, while cell extracts were used to assay intracellular concentration of glycerol, ATP, $\mathrm{Ca}^{2+}$ ions, oxidative stress markers and reactive oxygen species (ROS).The study confirmed that glycerol intracellular concentrations are directly related with its concentration in the incubation media, as well as hemolysis $(p<0.001)$ which increased significantly at glycerol concentrations higher form $200 \mathrm{mg} / \mathrm{dL}$. ROS intracellular level increased at all glycerol concentration tested $(p<0.01)$ and total thiols decreased at the highest concentrations. However, RBCs proved to be able to cope by activating their antioxidant defense system. Superoxide dismutase activity indeed increased at the highest glycerol concentrations $(p<0.001)$, while total antioxidant capacity and malonyldialdehyde, a typical product of lipid peroxidation by ROS, did not show significant changes. Moreover, no alterations in intracellular $\mathrm{Ca}^{2+}$ ions and ATP concentrations were found. In conclusion, glycerol-induced hemolysis can be related to the induced osmotic stress. In sheep, nutritional treatments should be designed to avoid reaching glycerol circulating concentrations higher than $200 \mathrm{mg} / \mathrm{dL}$.

Keywords: glycerol; sheep erythrocytes; osmotic stress; oxidative stress; $\mathrm{ATP} ; \mathrm{Ca}^{2+}$; hemolysis

\section{Introduction}

Glycerol is widely used as a feed supplement in small ruminant nutrition, both as replacer of corn grain in the diet [1-5] and to increase productive performance [6-12]. Glycerol is a hyperosmotic agent, lipid soluble, and it can pass cell membrane by simple 
diffusion, following a concentration gradient $[13,14]$. In previous studies $[15,16]$, we reported that oral administration of glycerol-based formulation in ewes causes a significant increase in circulating glycerol concentration (from 14.19 to $289.8 \mathrm{mg} / \mathrm{dL}$ ) and in plasma osmolality (from 0.316 to $0.378 \mathrm{osmol} / \mathrm{kg}$ ). These changes were associated with significant alteration in red blood cell (RBC) indices with a dose-related effect, which included shape alterations (increase in RBCs volume and distribution width) and a dilution in the amount of hemoglobin per volume unit [16]. These alterations were found $2 \mathrm{~h}$ after the oral administration of glucogenic formulations when glycerol concentrations in the bloodstream were higher than $\approx 200 \mathrm{mg} / \mathrm{dL}$. Similar effects were described in in vitro human glycerolized RBCs and were associated with an impaired functionality and reduced cell deformability, which in turn can affect the cells' capability to enter and transit the capillaries and to exchange gases, nutrients, and cell waste $[17,18]$.

The previously reported changes in RBC volume homeostasis consequent to the increase in glycerol concentration in the bloodstream are driven by glycerol entering the cells and by the consequent water drawing [19]. Changes in RBCs' volume homeostasis can affect their membrane integrity, leading to impaired functionality and increased eryptosis $[20,21]$. Previous studies indeed reported that glycerol is able to induce hemolysis of mammalian RBCs, likely consequent to the induced osmotic stress [22,23].

The above-mentioned alterations in RBC volume homeostasis may also result in oxidative stress [24]. In various cell types, ROS production is increased following hypotonic exposure $[25,26]$. Oxidative stress is caused by increasing productions or decreasing elimination of reactive oxygen species (ROS) in the cells [24], and, therefore, it can also be described as an imbalance between the prooxidants and antioxidants in the cells. Malonyldialdehyde (MDA), a typical product of lipid peroxidation by ROS, can crosslink phospholipids and proteins and oxidize protein sulfhydryl groups, thus damaging the cell membrane and causing hemolysis [27]. Moreover, both oxidative stress and hyperosmolarity can causes eryptosis by determining an increase in $\mathrm{Ca}^{2+}$ ions in the cytosol by the activation $\mathrm{Ca}^{2+}$ penetration through non-selective cation channels [28]. Normally cells have efficient antioxidant defense systems to face oxidative stress. Reduced glutathione (GSH) is the primary RBCs endogenous antioxidant and, given its ability to detoxify hydrogen peroxide and others electrophilic compounds, it is in the first line of defense against ROS. GSH have been reported to play a crucial role in maintenance in reduced state of hemoglobin -SH groups and in other enzymes [29]. However, the cellular redox defense system can also be altered by hyperosmotic conditions though a depletion in intracellular glutathione (GSH) availability [30]. Other antioxidant enzymes as superoxide dismutase (SOD) also provide primary protection from oxidative stress. SOD protects cells from toxic oxygen metabolites by converting superoxide radical into molecular oxygen and hydrogen peroxide. Superoxide radical is one of the more representative ROS in cells, and consequently SOD plays a key role on antioxidant defense [31]. Furthermore, the cells have a parallel non-enzymatic antioxidant system, and the Trolox equivalent antioxidant capacity (TEAC) is used to evaluate its capacity to face oxidative stress [32].

Starting from these premises, we hypothesized that elevated plasma glycerol can alter RBC homeostasis directly through changes in RBC volume and indirectly by leading to oxidative stress. The present study was thus designed to elucidate these direct and indirect consequences of RBCs' exposure to glycerol. RBCs were incubated in vitro with increasing glycerol concentrations, in the range of those found in in vivo studies after glycerol oral administration in ewes $[15,16]$. Cell lysis was measured and oxidative status was evaluated by assaying ROS intracellular concentration, SOD activity, total thiols, TEAC, and MDA in cell extracts. Moreover, to assess whether the alterations found could trigger eryptosis in vivo and alter cell metabolisms, intracellular concentration of $\mathrm{Ca}^{2+}$ ions and ATP were determined. Furthermore, to evaluate the possible effect of changes in cell volume on ROS production, sheep RBCs were exposed to hyper-osmotic and hypo-osmotic solutions and their intracellular ROS concentration was determined. Results obtained 
aimed at elucidating the possible side effects of glycerol administrations in ruminants on RBC viability.

\section{Materials and Methods}

\subsection{Reagents and Animals}

Unless otherwise specified, all chemical and reagents were purchased from Sigma. All procedures involving animals in this study were approved by the Local Animal Care and Use Committee (authorization code: 2899 of 17/01/2018). Ewes were confined outdoors with access to a sheltered area, at the experimental facilities of the Department of Veterinary Medicine at the University of Sassari, Italy, IT ( $40^{\circ} 43^{\prime} 40.33^{\prime \prime} \mathrm{N}, 8^{\circ} 33^{\prime} 1.33^{\prime \prime}$ E). Blood samples from four ewes were collected at fasting (07:00 a.m.) from the jugular vein using $9 \mathrm{~mL}$ vacuum collection tubes containing EDTA K2 (Vacutainer Systems Europe; Becton Dickinson, Meylan Cedex, France). Mean erythrocyte concentration was $12 \times 10^{9} / \mathrm{mL}$. Blood was then diluted to $0.12 \times 10^{9}$ cells $/ \mathrm{mL}$ with Hanks' Balanced Salt Solution (HBSS; Sigma code H6648). Whole blood was portioned in 10 samples and then diluted at the concentration of $0.10 \times 10^{6} \mathrm{RBCs} / \mu \mathrm{l}\left(0.10 \times 10^{9} / \mathrm{mL}\right)$ with HBSS supplemented with increasing glycerol concentrations $(0,25,50,100,150,200,250,300,350,400 \mathrm{mg} / \mathrm{dL})$. Samples were then incubated at $37^{\circ} \mathrm{C}$ during $4 \mathrm{~h}$. Glycerol stock solutions were prepared at $90 \%$ using $\mathrm{H}_{2} \mathrm{O}$ and vegetal Glycerol at $99.5 \%$ by Farmalabor (Canosa di Puglia, Provincia di Barletta-Andria-Trani, Italy; cod 018916). Following the incubation period, blood samples were gently centrifuged (100 $\mathrm{g}$ for $3 \mathrm{~min}$ ), and blood cells were separated from supernatant. Blood cell were used for the assay of intracellular glycerol, SOD, TEAC, total thiols, MDA, ATP, and $\mathrm{CA}^{2+}$ ions while supernatant was used for hemolysis. A separate set of samples was diluted at $7 \times 10^{6} \mathrm{RBCs} / \mathrm{mL}$ with glycerol and HBSS and incubated at $37^{\circ} \mathrm{C}$ during $4 \mathrm{~h}$ for ROS assay. All analyses for each sample (1 sample/ewe) were repeated in 4 replicates.

\subsection{Intracellular Glycerol Assay}

Glycerol assay was performed using Cell Biolabs' Free Glycerol Assay Colorimetric Kit (DBA Italia, Segrate, Milan, Italy; STA-398). Triton X100 extract RBC was used for measuring intracellular glycerol by a coupled enzymatic reaction system. The glycerol was phosphorylated and oxidized, producing hydrogen peroxide which reacts with the kit's Colorimetric Probe with maximum absorbance at $570 \mathrm{~nm}$ [16]. The glycerol concentrations were calculated using a standard curve with seven different points of standard glycerol concentrations from 0.06 to $3.68 \mathrm{mg} / \mathrm{dL}$ and expressed in $\mu \mathrm{g} / 10^{9}$ erythrocytes.

\subsection{Haemolysis}

The absorbance of the hemoglobin in the supernatant was assessed at $405 \mathrm{~nm}$. The absorbance of the supernatant of sheep $\mathrm{RBC}$ lysed in $\mathrm{H}_{2} \mathrm{O}$ was taken as $100 \%$ hemolysis [33].

\subsection{Osmolality Measurement}

Dilution media osmolality measurement $(\mathrm{Osm} / \mathrm{kg})$ was performed using a freezing point osmometer (Osmomat 030, Gonotec, Berlin, Germany).

\subsection{ROS Assay}

Blood samples diluted at the concentration of $7 \times 10^{6} \mathrm{RBCs} / \mathrm{mL}$ were added with the $2^{\prime}, 7^{\prime}$-dichlorodihydrofluorescein diacetate $\left(\mathrm{H}_{2} \mathrm{DCF}-\mathrm{DA}\right)$ probe at the final concentration of $3 \mu \mathrm{M}$. Within the cell, the esterases cleave the acetate groups on $\mathrm{H}_{2} \mathrm{DCF}-\mathrm{DA}$, thus trapping the reduced form of the probe $2^{\prime}, 7^{\prime}$-dichlorodihydrofluorescein $\left(\mathrm{H}_{2} \mathrm{DCF}\right)$. Intracellular ROS oxidize $\mathrm{H}_{2} \mathrm{DCF}$, yielding the fluorescent product, DCF. Fluorescence was measured using FLUOstar Omega microplate reader (BMG LABTECH). Excitation and emission wavelengths used for fluorescence quantification were 485 and $535 \mathrm{~nm}$, respectively. All fluorescence measurements (relative fluorescence unit-RFU) were corrected for background fluorescence. Data were expressed as means \pm SE [34,35]. 


\subsection{SOD, TEAC, Total Thiols, and MDA Assays}

Blood cells were treated with HBSS containing TritonX100 to $0.1 \%$ to obtain the cellar extract samples for SOD, TEAC, MDA, and total thiols assays. These assays were performed as reported in previous works [36,37]. All data were normalized for total cells and were assayed using an automatic cell counter instrument (Hematology analyzer Alcyon Mindray BC-5000, Shenzhen, China).

\subsubsection{SOD Assay}

SOD activity was assayed in cellular extracts and was measured enzymatically (at $470 \mathrm{~nm})$ as a decrease of the XTT (3'-(1- [(Phenylamino) -carbonyl] -3,4-tetrazolium) bis (4-methoxy-6-nitro) benzenesulphonic acid hydrate) reduction by superoxide anion generated by xanthine oxidase [38].

The values of SOD in the samples were calculated using a standard curve $(0.065-0.8 \mathrm{U} / \mathrm{mL})$ and expressed in $\mathrm{U} / 10^{9}$ erythrocytes. The number of erythrocytes was considered, taking the \% of hemolysis for each group, and one enzyme unit (IU) was defined as the amount of SOD capable of transforming $1.0 \mathrm{mmole} / \mathrm{min}$ of $\mathrm{O}_{2 \bullet} \bullet$.

\subsubsection{Total Thiols}

Total Thiols was assayed using the Ellman's Reagent 5,5-dithio-bis-(2-nitrobenzoic acid) (DTNB) solved in PBS. Thiols react with this compound (Figure 1), cleaving the disulfide bond to give 2-nitro-5-thiobenzoate $(\mathrm{TNB}-)$, which ionizes to the $\mathrm{TNB}^{2-}$ dianion in water at neutral and alkaline $\mathrm{pH}$. This $\mathrm{TNB}^{2-}$ ion has a yellow color.

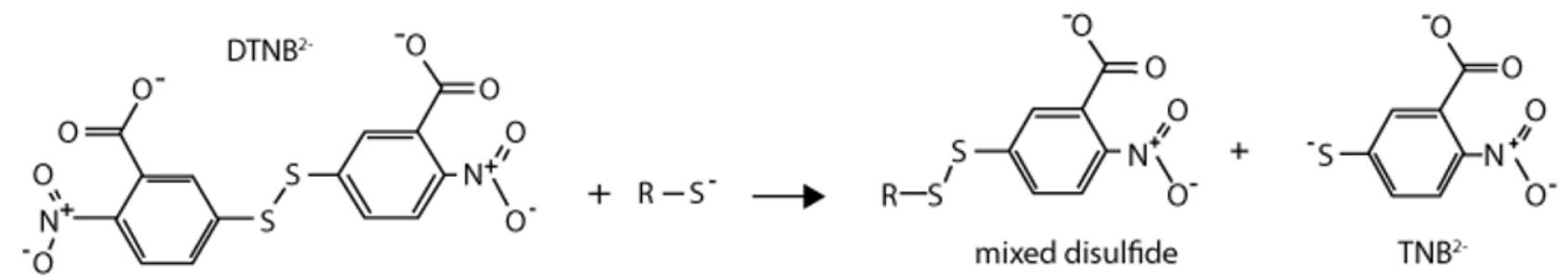

Figure 1. Ellman's reaction.

The TNB2-was quantified in a spectrophotometer by measuring the absorbance of visible light at $412 \mathrm{~nm}$, using an extinction coefficient of $14,150 \mathrm{M}^{-1} \mathrm{~cm}^{-1}$ for dilute buffer solutions [39]. The values of Thiols in the samples were expressed in nmol $/ 10^{9}$ erythrocytes.

\subsubsection{TEAC Assay}

TEAC was determined using the method described by Re et al. and modified by Lewinska et al. [40]. Briefly, a fresh solution was prepared by dissolving $19.5 \mathrm{mg} 2,20$-azinobis (3- ethylbenzthiazoline -6-sulphonic acid [ABTS]) and $3.3 \mathrm{mg}$ potassium persulphate in $7 \mathrm{~mL}$ of $0.1 \mathrm{~mol} / \mathrm{L}$ phosphate buffer, $\mathrm{pH}$ 7.4. This solution was stored in the dark for $12 \mathrm{~h}$ for completion of the reaction. ABTS solution was diluted (usually approximately $1: 80$ ) in $0.1 \mathrm{~mol} / \mathrm{L}$ phosphate buffer, $\mathrm{pH} 7.4$, to give an absorbance reading at $734 \mathrm{~nm}$ of 1.0 and mixed thoroughly. The antioxidant capacity was expressed as TEAC, that is, the concentration of trolox producing the same effect as the sample studied. The values of TEAC in the samples were calculated using a standard curve $(5-20 \mathrm{mM}$ trolox in a total volume of $550 \mathrm{~mL}$ ) and were expressed as $\mu$ moles of trolox equivalent/Cell extract ( $\mu$ molTEAC $/ 10^{9}$ erythrocytes).

\subsubsection{MDA Assay}

MDA, one of the several low-molecular-weight end-products of lipid peroxidation, was evaluated by the TBARS assay using thiobarbituric acid and a spectrophotometric method according to the TBA test described by Spanier and Traylor [41], with some 
modifications. The values of MDA in the samples were calculated using a standard curve $(2-100 \mu \mathrm{M})$ and expressed in $\mathrm{nmol} / 10^{9}$ erythrocytes.

\section{7. $\mathrm{Ca}^{2+}$ Ions Assay}

The determination of intracellular $\mathrm{Ca}^{2+}$ ions concentration was performed using the $\mathrm{Ca}^{2+}$ ions Assay Kit (Hagen Diagnostica cod. 001-0037). HBSS containing $\mathrm{CaCl}_{2} 1 \mathrm{mM}$ and $\mathrm{MgCl}_{2} 0.5 \mathrm{mM}(0.285 \mathrm{osmol} / \mathrm{Kg})$ was used for blood dilution. After incubation with different concentrations of glycerol and centrifugation, blood cells were treated with PBS containing TritonX100 0.1\% and the cell extract was assayed (at 570nm) with a direct colorimetric assay based on the O-Cresolphtalein (OCPC) method without deproteinization of the sample [42].

$\mathrm{Ca}^{2+}$ ions concentrations were expressed in nmol $/ 10^{9}$ erythrocytes using a $\mathrm{Ca}^{2+}$ ions standard of $25 \mu \mathrm{M}$ and normalized for cell number.

\subsection{Extraction and Measurement of Intracellular ATP}

Determination of intracellular ATP concentration was performed by the enzymatic assay as described by Bergmeyer et al. [43]. Briefly, cells were treated with $0.1 \mathrm{~mL}$ of ice-cold $0.6 \mathrm{M}$ perchloric acid added to each Eppendorf tube containing erythrocytes with different glycerol concentrations and kept for $15 \mathrm{~min}$, for the extraction of nucleotides. After, the suspension was centrifuged in an Eppendorf Microfuge ( $3 \mathrm{~min}$ at $6000 \mathrm{~g}$ ) and the supernatant was neutralized with $15 \mu \mathrm{L}$ of $3.5 \mathrm{M} \mathrm{K}_{2} \mathrm{CO}_{3}$ [44] and measured spectrophotometrically at $340 \mathrm{~nm}$ using NADH-linked enzyme-coupled assays. The glucose 6 phosphate dehydrogenase (G6PD) and hexokinase (HK) were used with glucose, nicotinamide adenine dinucleotide phosphate (NADP+), sample $(25 \mu \mathrm{L})$, all in TRAP buffer $(0.1 \mathrm{M}, \mathrm{pH} 7.6)$. ATP was determined from the formation of NADPH. The values of ATP in the samples were calculated using a standard curve $(0.055-50 \mu \mathrm{M})$ and expressed in $\mathrm{nmol} / 10^{9}$ erythrocytes.

\subsection{ROS Production Using Solutes with Different Osmolality without Glycerol}

Blood samples were diluted at the concentration of $7 \times 10^{6} \mathrm{RBCs} / \mathrm{mL}$ in 5 different hyper-osmotic solutions and 6 different hypo-osmotic solutions (Table 1 ). The hyperosmotic solutions were prepared with the addition of an impermeant solute (starch from Merck, C.I.20470), covering the range of osmolarity induced by glycerol in this work. Hypoosmotic solutions were prepared by adding purified water to a PBS solution to obtain the osmolarity range reported in Table 1 . After dilution, blood samples were incubated at $37^{\circ} \mathrm{C}$ during $4 \mathrm{~h}$. At the end of the incubation period, ROS production was determined as above described.

Table 1. Osmolality values of 5 different hyper-osmotic solutions and 6 different hypo-osmotic solutions. Hyperosmotic solutions were prepared by adding starch to a PBS solution. Hypo-osmotic solutions were prepared adding purified water to a PBS solution.

\begin{tabular}{ccc}
\hline & Osmol/Kg & Starch Concentrations $\mathbf{~ m} / \mathbf{m L}$ \\
\hline & 0.370 & 3.50 \\
Hyper-osmotic & 0.349 & 2.91 \\
solutions & 0.337 & 2.23 \\
& 0.326 & 1.69 \\
& 0.319 & 1.44 \\
\hline Iso-osmotic solution & 0.299 & 0.00 \\
\hline & 0.270 & 0.00 \\
Hypo-osmotic & 0.260 & 0.00 \\
solutions & 0.251 & 0.00 \\
& 0.237 & 0.00 \\
& 0.280 & 0.00 \\
& 0.217 & 0.00 \\
\hline
\end{tabular}




\subsection{Statistical Analysis}

Data are expressed as means \pm SE. Results were analyzed by a one-way ANOVA test, used to compare intracellular glycerol, oxidative stress markers, and hemolysis, using Minitab 17 Statistical Software (Minitab, Inc., 2010, State College, PA, USA). As post-hoc test, Tukey' test was used to highlight differences between groups. Statistical significance was accepted at $p<0.05$. The number of RBCs used to express the results was corrected taking into consideration the $\%$ of hemolysis in each group.

\section{Results}

The osmolality of dilution media supplemented with increasing glycerol concentrations is shown in Table 2. As expected, media osmolality increased proportionally with glycerol concentration. These osmolality values are in the range of those found in vivo (from 0.316 to $0.378 \mathrm{osmol} / \mathrm{Kg}$ ) [16] in ewe's plasma after oral administration of glycerol as nutritional supplement.

Table 2. Osmolality values of media supplemented with increasing glycerol concentrations. Uppercase letters indicate differences between groups ( $p<0.01$-one-way ANOVA-Tukey post hoc test).

\begin{tabular}{ccc}
\hline [Glycerol (mg/dL)] & Osmolality $(\mathbf{O s m} / \mathbf{K g}) \pm$ S.E. \\
\hline 0 & $0.299 \pm 0.002$ & $\mathrm{~A}$ \\
25 & $0.312 \pm 0.001$ & $\mathrm{~B}$ \\
50 & $0.319 \pm 0.001$ & $\mathrm{BC}$ \\
100 & $0.324 \pm 0.002$ & $\mathrm{CD}$ \\
150 & $0.332 \pm 0.002$ & $\mathrm{DE}$ \\
200 & $0.337 \pm 0.001$ & $\mathrm{EF}$ \\
250 & $0.344 \pm 0.002$ & $\mathrm{FG}$ \\
300 & $0.351 \pm 0.002$ & $\mathrm{GH}$ \\
350 & $0.360 \pm 0.001$ & $\mathrm{HI}$ \\
400 & $0.367 \pm 0.002$ & $\mathrm{I}$ \\
\hline
\end{tabular}

Intracellular glycerol concentrations significantly increased after RBC incubation in media containing glycerol at concentrations higher than $200 \mathrm{mg} / \mathrm{dL}(p<0.01$; Figure 2, panel A). At the same concentration range (from 200 to $400 \mathrm{mg} / \mathrm{dL}$ ), hemolysis significantly increased ( $p<0.01$; Figure 2, panel B).
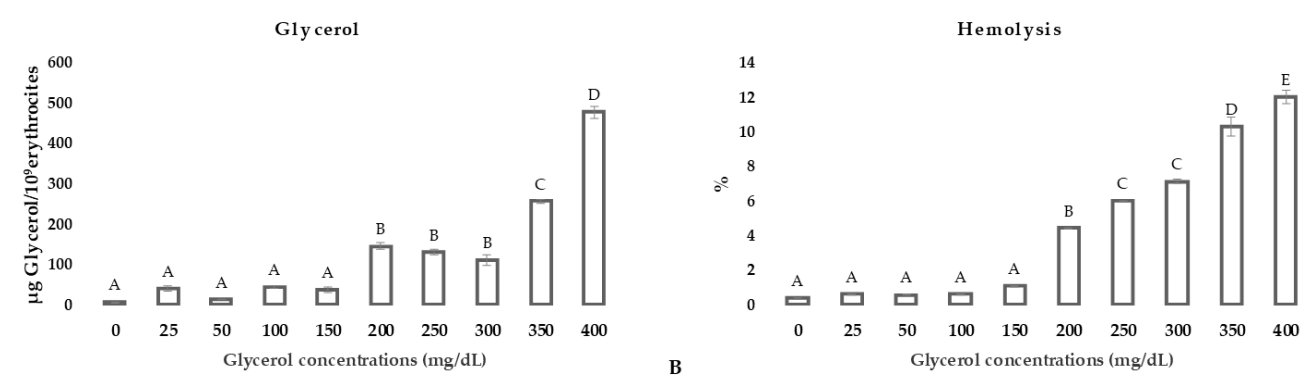

Figure 2. Intracellular glycerol concentrations after RBC incubation in media supplemented with glycerol in concentrations ranging from 0 to $400 \mathrm{mg} / \mathrm{dL}$ (panel A); Hemolysis (\%) after RBC incubation in media supplemented with glycerol in concentrations ranging from 0 to $400 \mathrm{mg} / \mathrm{dL}$ (panel B). Uppercase letters indicate significant differences between groups $(p<0.001$; one-way ANOVA-Tukey post hoc test).

ROS production increased significantly in RBC incubated with all glycerol supplemented media compared to the control ( $p<0.01$; Figure 3 , panel A). In contrast SOD activity increased significantly only at high glycerol concentrations (350 and $400 \mathrm{mg} / \mathrm{dL} ; p<0.001$ Figure 3, panel B). Total thiol variation was not related with glycerol doses (Figure 3, 
panel C). TEAC and MDA did not show changes in respect to the control group (Figure 3, panels $\mathrm{D}, \mathrm{E})$.
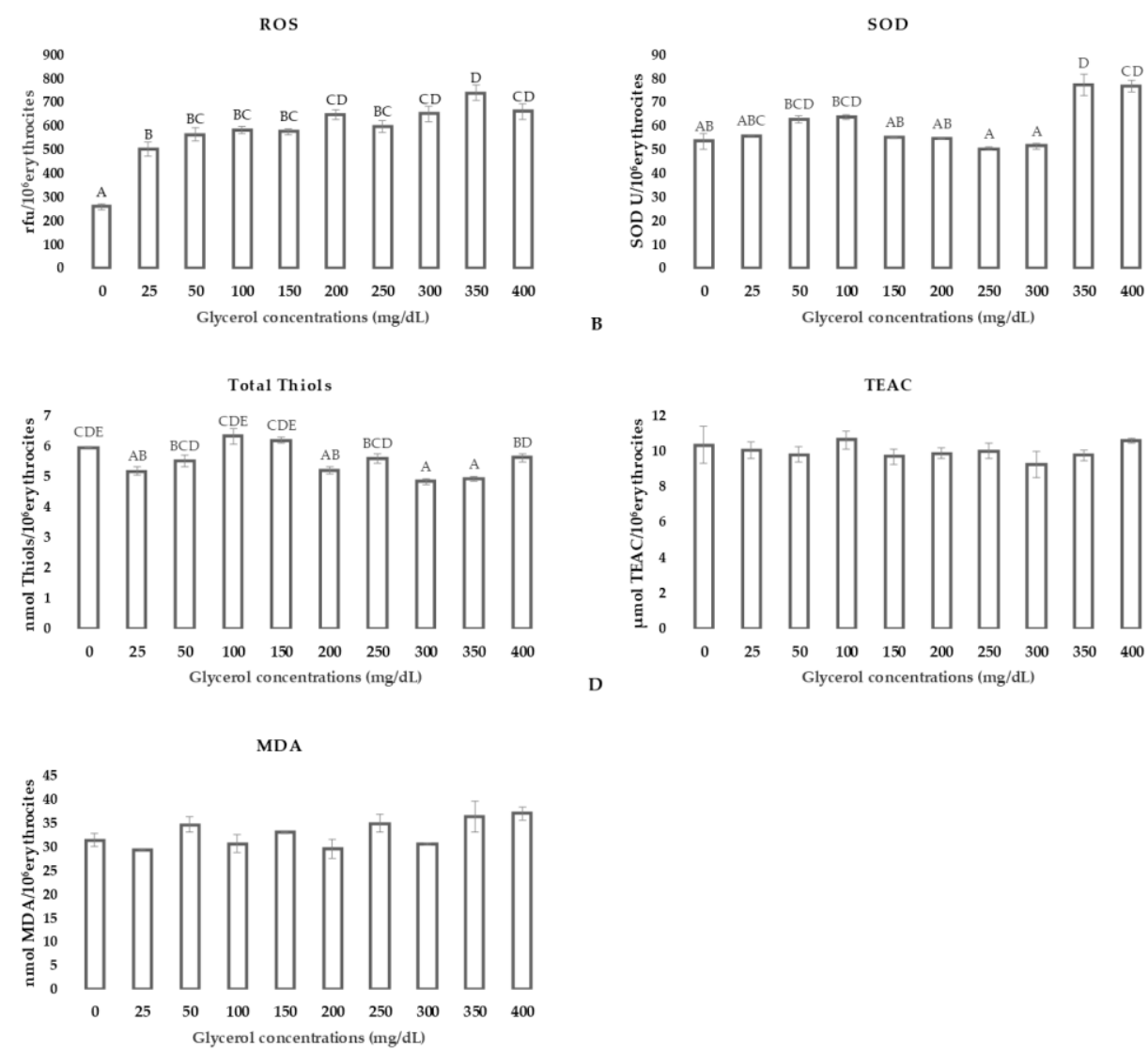

Figure 3. ROS production (panel A), SOD activity (panel B), total thiol concentrations (panel C), total anti-oxidant capacity (TEAC; panel D), and MDA (panel E) concentration in RBCs after incubation in media supplemented with glycerol in concentrations ranging from 0 to $400 \mathrm{mg} / \mathrm{dL}$. Uppercase letters indicate significant differences between groups: $\operatorname{ROS} p<0.01$; TEAC $p=0.764$; total thiols $p<0.05 ; \mathrm{SOD} p<0.05 ; \mathrm{MDA} p=0.062$ (one-way ANOVA-Tukey post hoc test).

Although in our system we highlighted osmotic and oxidative stress, the intracellular $\mathrm{Ca}^{2+}$ ions (Figure 4, panel A) concentration did not change after incubation in media supplemented with glycerol when compared to the control group. Moreover, ATP concentration showed a high variability (Figure 4, panel B) and differences among groups could not be related to glycerol concentrations (Table 3).
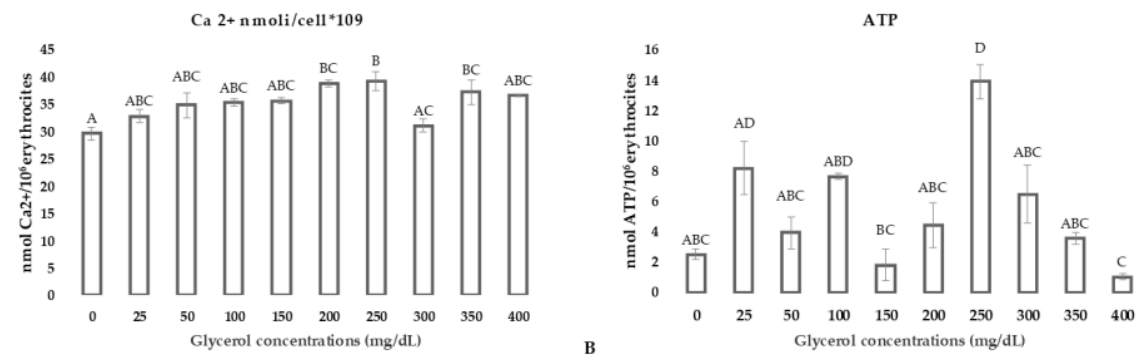

Figure 4. Intracellular $\mathrm{Ca}^{2+}$ (panel A) and ATP concentration (panel B) in RBCs after incubation in media supplemented with glycerol in concentrations ranging from 0 to $400 \mathrm{mg} / \mathrm{dL}$. Uppercase letters indicate significant differences between groups: $\mathrm{Ca}^{2+} p<0.05$ ATP $p<0.05$; (one-way ANOVA-Tukey post hoc test). 
Table 3. Pearson correlation coefficients between intracellular glycerol, oxidative stress markers, and hemolisys. $p$ values are shown within parentheses.

\begin{tabular}{|c|c|c|c|c|c|c|c|c|c|}
\hline & Glycerol & Osmolality & Haemolysis & ROS & MDA & $\mathrm{Ca}^{2+}$ Ions & SOD & Total Thiols & ATP \\
\hline Osmolality & $\begin{array}{c}0.836 \\
(0.003)\end{array}$ & & & & & & & & \\
\hline Haemolysis & $\begin{array}{c}0.915 \\
(<0.001)\end{array}$ & $\begin{array}{c}0.933 \\
(<0.001)\end{array}$ & & & & & & & \\
\hline ROS & $\begin{array}{c}0.565 \\
(0.088)\end{array}$ & $\begin{array}{c}0.853 \\
(0.002)\end{array}$ & $\begin{array}{c}0.669 \\
(0.034)\end{array}$ & & & & & & \\
\hline MDA & $\begin{array}{l}0.631 \\
(0.05)\end{array}$ & $\begin{array}{c}0.582 \\
(0.078)\end{array}$ & $\begin{array}{c}0.621 \\
(0.055)\end{array}$ & $\begin{array}{c}0.382 \\
(0.276)\end{array}$ & & & & & \\
\hline $\mathrm{Ca}^{2+}$ & $\begin{array}{c}0.425 \\
(0.221)\end{array}$ & $\begin{array}{l}0.537 \\
(0.11)\end{array}$ & $\begin{array}{c}0.393 \\
(0.262)\end{array}$ & $\begin{array}{c}0.662 \\
(0.037)\end{array}$ & $\begin{array}{c}0.420 \\
(0.227)\end{array}$ & & & & \\
\hline SOD & $\begin{array}{c}0.701 \\
(0.024)\end{array}$ & $\begin{array}{c}0.514 \\
(0.129)\end{array}$ & $\begin{array}{c}0.573 \\
(0.083)\end{array}$ & $\begin{array}{c}0.468 \\
(0.173)\end{array}$ & $\begin{array}{c}0.669 \\
(0.034)\end{array}$ & $\begin{array}{c}0.279 \\
(0.435)\end{array}$ & & & \\
\hline $\begin{array}{l}\text { Total } \\
\text { Thiols }\end{array}$ & $\begin{array}{c}-0.282 \\
(0.43)\end{array}$ & $\begin{array}{l}-0.424 \\
(0.223)\end{array}$ & $\begin{array}{l}-0.511 \\
(0.131)\end{array}$ & $\begin{array}{l}-0.455 \\
(0.186)\end{array}$ & $\begin{array}{l}-0.012 \\
(0.973)\end{array}$ & $\begin{array}{l}-0.022 \\
(0.953)\end{array}$ & $\begin{array}{l}-0.083 \\
(0.819)\end{array}$ & & \\
\hline ATP & $\begin{array}{l}-0.274 \\
(0.444)\end{array}$ & $\begin{array}{l}-0.059 \\
(0.871)\end{array}$ & $\begin{array}{l}-0.117 \\
(0.748)\end{array}$ & $\begin{array}{c}0.059 \\
(0.872)\end{array}$ & $\begin{array}{l}-0.208 \\
(0.565)\end{array}$ & $\begin{array}{c}0.234 \\
(0.515)\end{array}$ & $\begin{array}{l}-0.471 \\
(0.169)\end{array}$ & $\begin{array}{l}-0.108 \\
(0.767)\end{array}$ & \\
\hline TEAC & $\begin{array}{c}0.248 \\
(0.489)\end{array}$ & $\begin{array}{c}-0.189 \\
(0.6)\end{array}$ & $\begin{array}{c}-0.07 \\
(0.847)\end{array}$ & $\begin{array}{l}-0.327 \\
(0.356)\end{array}$ & $\begin{array}{c}0.119 \\
(0.742)\end{array}$ & $\begin{array}{c}0.074 \\
(0.839)\end{array}$ & $\begin{array}{c}0.357 \\
(0.311)\end{array}$ & $\begin{array}{c}0.604 \\
(0.064)\end{array}$ & $\begin{array}{l}-0.049 \\
(0.893)\end{array}$ \\
\hline
\end{tabular}

As reported in Table 3, the intracellular glycerol concentrations were positively correlated with media osmolality, hemolysis $(p<0.01)$, SOD activity, and MDA concentration $(p<0.05)$. In turn, osmolality and hemolysis were positively correlated with intracellular ROS production $(p<0.05)$, and SOD had a positive correlation with MDA $(p<0.05)$.

The effect of cell shrinkage or volume expansion on ROS production has been also studied. As reported in Figure 5, ROS production in RBCs did not change after incubation in hyper-osmotic solutions, showing a significant decrease only at the highest osmolality values. On the other hand, when RBCs were exposed to hypo-osmotic solutions, ROS production increased significantly in all the osmolality values tested.

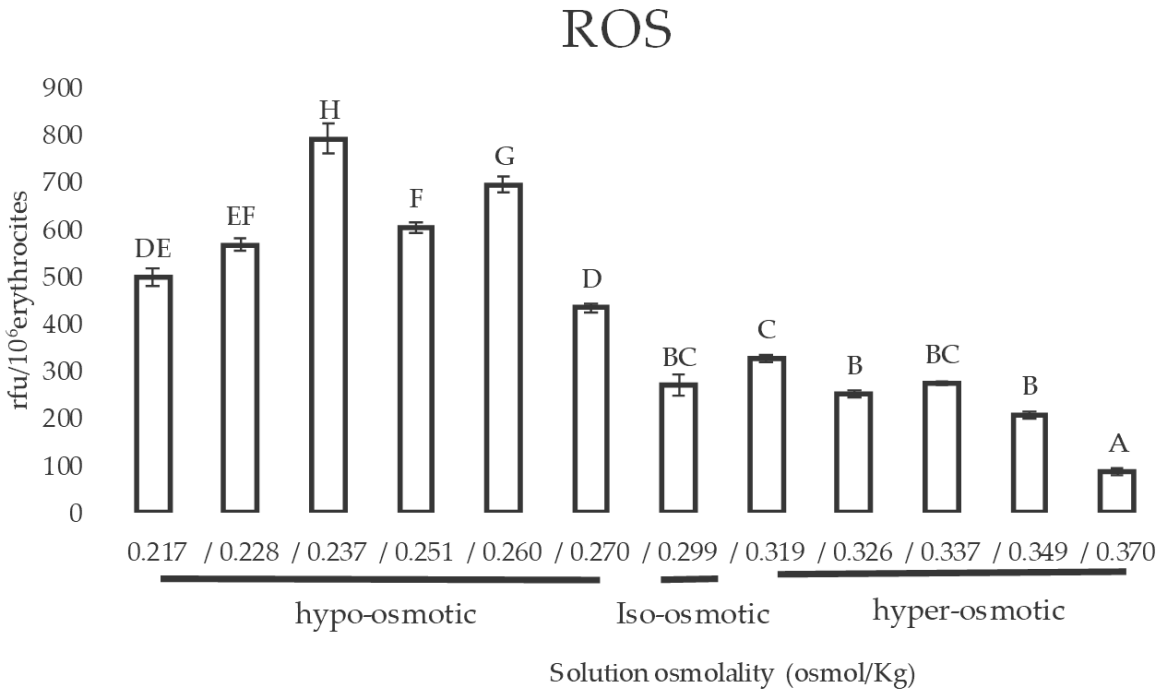

Figure 5. ROS production in sheep RBCs after incubation with 5 different hyper-osmotic solutions and 6 different hypo-osmotic solutions. Uppercase letters indicate significant differences between groups: $p<0.05$ (one-way ANOVA-Tukey post hoc test). 


\section{Discussion}

The EU legislation approved glycerol as an animal feed additive with no restrictions on animal species or quantity that may be fed [45]. However, as recently reported, the increase in plasma glycerol circulating concentrations following its administration may pose negative effects on animal welfare such as increasing plasma osmolality and consequent alterations of RBCs indices [16].

After glycerol oral administration, its concentrations indeed increase sharply in the bloodstream $[15,16]$. Glycerol is lipid soluble and passes the RBC membrane following a concentration gradient [19]. In sheep, glycerol is transported in RBCs only via simple diffusion [13], and hence it has a lower permeability coefficient compared to humans [14] where it also enters by facilitated diffusion through aquaporins [13]. In this study, we showed that intracellular glycerol concentrations in sheep RBCs increased significantly compared to the control group after incubation in media supplemented with concentrations higher than $200 \mathrm{mg} / \mathrm{dL}$. Above this concentration, hemolysis also increased significantly compared to the control group and a highly positive correlation between hemolysis and intracellular glycerol concentrations was observed. Previous studies reported that glycerol is able to induce hemolysis of mammalian RBCs, likely consequent to the induces osmotic stress [22,23]. This effect is probably correlated to the entry of glycerol into RBCs, which can cause water drawing [45]. Before glycerol and water diffuse into the cells and cause cellular swelling, an osmotically driven water efflux and a concomitant decrease in cell volume occur [46]. In this process, it is necessary to maintain the cell volume within the osmotic tolerance limits, defined as the extent of volume excursions the cell can withstand before irreversible damage occurs [47]. Glycerol is able to induce a severe osmotic stress to the cells [48] and, according to our findings, concentrations higher from $200 \mathrm{mg} / \mathrm{mL}$ are above the osmotic tolerance limits of sheep RBCs. In the sheep, these blood concentrations are obtained when administering $170-220 \mathrm{~mL}$ of glycerol per dose $(22.5-27.4 \%$ of the dry matter intake in Sarda adult ewes). Based on our previous findings, lower doses should be preferred for flushing dairy ewes $(70 \mathrm{~mL}, 12.9 \%$ of the dry matter intake in Sarda adult ewes), as they proved to be effective at metabolic level without causing alterations in RBC indexes and possibly their functionality [16].

In the present study, each glycerol concentration tested caused a significant increase in the production of intracellular ROS, which was also positively correlated with hemolysis. In other studies, incubation of RBCs with glycerol was not associated with an increase in RBCs' ROS production [49]. The concentration used in the above-mentioned study (3.5 mg/dL) [49] was, however, significantly lower than the ones tested in the present one. The increase in RBCs' ROS production found in the present study may thus be linked directly to glycerol entry in the cells, to the alterations in cell volume, or to a combination of both. ROS production may be directly linked to cell swelling as it also increased in hypo-osmotic conditions. This hypothesis is supported by previous studies reporting in various cell types an increase in ROS production following hypotonic exposure $[25,26]$.

However, the increase of SOD activity found at the highest glycerol concentrations, i.e., 350 and $400 \mathrm{mg} / \mathrm{dL}$, suggest that RBCs were able to activate their antioxidant defense systems in response to the glycerol addition in incubation media. Even though total thiols decreased at these concentrations, no changes in MDA intracellular concentrations and total antioxidant capacity were found after incubation in glycerol supplemented media. The increase in MDA concentration is indeed significantly correlated with a decrease in the cell antioxidant capacity [50]. In the present study, RBCs thus proved to be able to cope with the increased ROS production: in fact, MDA did not increase and the antioxidant defenses did not decrease following the glycerol treatment.

Under in vivo conditions, oxidative stress can induce eryptosis through an increase in cellular $\mathrm{Ca}^{2+}$ ions [51]. Changes in intracellular $\mathrm{Ca}^{2+}$ ions concentrations under stress conditions represent indeed one of the most important trigger mechanisms of metabolic regulation finally underlying death or adaptation of RBCs to the extreme treatments [52]. High intracellular $\mathrm{Ca}^{2+}$ ion concentration is responsible for the activation of the phospholipid 
scramblase [53]. Scramblases destroy the asymmetric distribution of lipids, transferring them from one layer to another by a concentration gradient without energy consumption [54]. These membrane modifications recall macrophages, thus preventing hemolysis from occurring [55]. Instead, under in vitro conditions, damaged erythrocytes cannot be eliminated and undergo hemolysis [33]. In the present study, incubation of RBCs in glycerol supplemented media did not change intracellular $\mathrm{Ca}^{2+}$ ion concentration. In the range of glycerol concentrations tested, the $\mathrm{RBC}$ systems that control $\mathrm{Ca}^{2+}$ ions concentrations thus proved to be able to maintain a low $\mathrm{Ca}^{2+}$ level. Erytroptosis can also result from ATP depletion [56]. ATP values found in sheep RBCs in the present study confirm that functional metabolic activity was preserved at all concentrations tested. Therefore, we may speculate that observed hemolysis is caused by osmotic stress, rather than by changes in intracellular $\mathrm{Ca}^{2+}$ ions and ATP concentrations.

\section{Conclusions}

In conclusion, results found in the present study showed that the exposition of sheep RBCs to glycerol concentration above $200 \mathrm{mg} / \mathrm{dL}$ can cause hemolysis under in vitro conditions. Hemolysis is likely caused by the severe osmotic stress induced by glycerol, rather than by oxidative stress, since RBCs proved to be able to cope with the increased ROS production. The reported increase in ROS production was likely linked to cell swelling consequent to glycerol entry in the cells, even if we cannot rule out a possible direct effect of glycerol. In addition, no alterations in intracellular $\mathrm{Ca}^{2+}$ ions and ATP concentrations were found after incubation at the range of glycerol concentrations tested. These results thus suggest that, in sheep, to avoid RBCs' osmotic stress, glycerol-based nutritional treatments should be designed to reach circulating concentrations not exceeding the limit of $200 \mathrm{mg} / \mathrm{dL}$. This conclusion is supported by a previous in vivo study reporting that when this threshold level is exceeded, RBC shape alterations are observed [16].

Author Contributions: Conceptualization, F.B. and V.P.; methodology, V.P., F.D.S., and C.P.; analysis, C.P., F.D.S., and V.P.; investigation, V.P., F.D.S., and C.P.; data curation, F.B., C.P., and V.P.; writingoriginal draft preparation, F.B. and V.P.; writing-review and editing, C.P. and F.D.S.; funding acquisition, F.B. All authors have read and agreed to the published version of the manuscript.

Funding: This work was supported by "Fondo di Ateneo per la ricerca 2019". F.D.S. received a PhD grant funded by the Italian Ministry of Education, University and Research-“PON Dottorati Innovativi con caratterizzazione industriale" 2017-grant code DOT1629893. C.P. received a research grant funded by the Italian Ministry of Education, University and Research-PON ricerca innovazione 2014 2020, (asse 1 "capitale umano", azione I.2 A.I.M.) grant code AIM 1887720-1.

Institutional Review Board Statement: The study was conducted according to the guidelines of the Declaration of Helsinki and approved by the Ethics Committee of the UNIVERSITY OF SASSARI (authorization code: 2899 of 17/01/2018), in compliance with the European Union Directive 86/609/EC and the recommendation of the Commission of the European Communities 2007/526/EC. 2.1.

Data Availability Statement: The dataset is available upon request.

Conflicts of Interest: The authors declare no conflict of interest.

\section{References}

1. Van Cleef, E.H.C.B.; Uwituze, S.; Alvarado-Gilis, C.A.; Miller, K.A.; Van Bibber-Krueger, C.L.; Aperce, C.C.; Drouillard, J.S. Elevated concentrations of crude glycerin in diets for beef cattle: Feedlot performance, carcass traits and ruminal metabolism. $J$. Anim. Sci. 2019, 97, 4341-4348. [CrossRef]

2. Gunn, P.J.; Neary, M.K.; Lemenager, R.P.; Lake, S.L. Effects of crude glycerin on performance and carcass characteristics of finishing wether lambs. J. Anim. Sci. 2010, 88, 1771-1776. [CrossRef]

3. Almeida, M.T.C.; Paschoaloto, J.R.; Perez, H.L.; Carvalho, V.B.; Homem Junior, A.C.; Favaro, V.R.; Blair, H.T.; Ezequiel, J.M.B. Effect of adding crude glycerine to diets with feed additives on the feed intake, ruminal degradability, volatile fatty acid concentrations and in vitro gas production of feedlot Nellore cattle. J. Anim. Physiol. Anim. Nutr. 2019, 103, 988-996. [CrossRef]

4. Khattab, M.S.A. Glycerol as Feedstuff for Ruminant. Sci. Int. 2015, 3, 90-94. [CrossRef] 
5. Carvalho, V.B.; Leite, R.F.; Almeida, M.T.C.; Paschoaloto, J.R.; Carvalho, E.B.; Lanna, D.P.D.; Perez, H.L.; Van Cleef, E.H.C.B.; Homem Junior, A.C.; Ezequiel, J.M.B. Carcass characteristics and meat quality of lambs fed high concentrations of crude glycerin in low-starch diets. Meat Sci. 2015, 110, 285-292. [CrossRef] [PubMed]

6. Berlinguer, F.; Gonzalez-Bulnes, A.; Contreras-Solis, I.; Spezzigu, A.; Torres-Rovira, L.; Succu, S.; Naitana, S.; Leoni, G.G. Glucogenic supply increases oocyte developmental competence in sheep. Reprod. Fertil. Dev. 2012, 24, 1055-1062. [CrossRef]

7. Porcu, C.; Pasciu, V.; Succu, S.; Baralla, E.; Manca, M.E.E.; Serra, E.; Leoni, G.G.G.; Dattena, M.; Bomboi, G.C.C.; Molle, G.; et al. Glucogenic treatment creates an optimal metabolic milieu for the conception period in ewes. Domest. Anim. Endocrinol. 2017, 59, 105-115. [CrossRef] [PubMed]

8. Novais-Eiras, D.; de Carvalho, G.G.P.; Leite, L.C.; Eiras, C.E.; de Freitas, J.E.; dos Pina, D.S.; Ferreira, F.G.; dos Santos, G.T.; Grande, P.A. Crude glycerin in the feed supplementation of lactating goats on pasture. Small Rumin. Res. 2018, 168, 39-46. [CrossRef]

9. Polizel, D.M.; Susin, I.; Gentil, R.S.; Ferreira, E.M.; de Souza, R.A.; Freire, A.P.A.; Pires, A.V.; Ferraz, M.V.C.; Rodrigues, P.H.M.; Eastridge, M.L. Crude glycerin decreases nonesterified fatty acid concentration in ewes during late gestation and early lactation. J. Anim. Sci. 2017, 95, 875-883. [CrossRef] [PubMed]

10. Thoh, D.; Pakdeechanuan, P.; Chanjula, P. Effect of supplementary glycerin on milk composition and heat stability in dairy goats. Asian-Australas. J. Anim. Sci. 2017, 30, 1711-1717. [CrossRef] [PubMed]

11. Webb, R.; Buratini, J.; Hernandez-Medrano, J.H.; Gutierrez, C.G.; Campbell, B.K. Follicle development and selection: Past, present and future. Anim. Reprod. 2016, 13, 234-249. [CrossRef]

12. Gutierrez, C.G.; Ferraro, S.; Martinez, V.; Saharrea, A.; Cortez, C.; Lassala, A.; Basurto, H.; Hernandez, J. Increasing ovulation quota: More than a matter of energy. Acta Sci. Vet. 2011, 39, 305-316.

13. Carlsen, A.; Wieth, J.O. Glycerol Transport in Human Red Cells. Acta Physiol. Scand. 1976, 97, 501-513. [CrossRef]

14. Scott, L. A Chapter 7 Diffusion Across a Sheep Red Blood Cell Membrane. Cell 1993, 14, 115-140.

15. Porcu, C.; Manca, C.; Cabiddu, A.; Dattena, M.; Gallus, M.; Pasciu, V.; Succu, S.; Naitana, S.; Berlinguer, F.; Molle, G. Effects of short-term administration of a glucogenic mixture at mating on feed intake, metabolism, milk yield and reproductive performance of lactating dairy ewes. Anim. Feed Sci. Technol. 2018, 243, 10-21. [CrossRef]

16. Porcu, C.; Sotgiu, F.D.; Pasciu, V.; Cappai, M.G.; Barbero-Fernández, A.; Gonzalez-Bulnes, A.; Dattena, M.; Gallus, M.; Molle, G.; Berlinguer, F. Administration of glycerol-based formulations in sheep results in similar ovulation rate to eCG but red blood cell indices may be affected. BMC Vet. Res. 2020, 16, 207. [CrossRef]

17. Bizjak, D.A.; Jungen, P.; Bloch, W.; Grau, M. Cryopreservation of red blood cells: Effect on rheologic properties and associated metabolic and nitric oxide related parameters. Cryobiology 2018. [CrossRef] [PubMed]

18. Hoffmann, E.K.; Lambert, I.H.; Pedersen, S.F. Physiology of cell volume regulation in vertebrates. Physiol. Rev. 2009, 89, 193-277. [CrossRef] [PubMed]

19. Valeri, C.R.; Ragno, G. Cryopreservation of human blood products. Transfus. Apher. Sci. 2006. [CrossRef]

20. Narla, J.; Mohandas, N. Red cell membrane disorders. Int. J. Lab. Hematol. 2017, 39, 47-52. [CrossRef]

21. Glogowska, E.; Gallagher, P.G. Disorders of erythrocyte volume homeostasis. Int. J. Lab. Hematol. 2015, 37, 85-91. [CrossRef]

22. Arakawa, M.; Kondo, T.; Mitsui, H.; Suzuki, S.; Shiba, M. Glycerol-induced hemolysis of mammalian erythrocytes and inhibition of the lysis by fructose. Nihon Yakurigaku Zasshi 1977, 73, 541-547. [CrossRef]

23. Zou, C.-G.; Agar, N.S.; Jones, G.L. Haemolysis of human and sheep red blood cells in glycerol media: The effect of $\mathrm{pH}$ and the role of band 3. Comp. Biochem. Physiol. Part A Mol. Integr. Physiol. 2000, 127, 347-353. [CrossRef]

24. Bissinger, R.; Bhuyan, A.A.M.; Qadri, S.M.; Lang, F. Oxidative stress, eryptosis and anemia: A pivotal mechanistic nexus in systemic diseases. FEBS J. 2019, 286, 826-854. [CrossRef]

25. Gagnon, K.B.E.; England, R.; Delpire, E. Characterization of SPAK and OSR1, Regulatory Kinases of the Na-K-2Cl Cotransporter. Mol. Cell. Biol. 2006. [CrossRef] [PubMed]

26. Friis, M.B.; Vorum, K.G.; Lambert, I.H. Volume-sensitive NADPH oxidase activity and taurine efflux in NIH3T3 mouse fibroblasts. Am. J. Physiol. Cell Physiol. 2008. [CrossRef]

27. Slatter, D.A.; Bolton, C.H.; Bailey, A.J. The importance of lipid-derived malondialdehyde in diabetes mellitus. Diabetologia 2000, 43, 550-557. [CrossRef] [PubMed]

28. Repsold, L.; Joubert, A.M. Eryptosis: An Erythrocyte's Suicidal Type of Cell Death. Biomed. Res. Int. 2018, 2018, 1-10. [CrossRef] [PubMed]

29. Chaudhary, M.K.; Singh, S.; Rizvi, S.I. Redox imbalance in a model of rat mimicking Hutchinson-Gilford progeria syndrome. Biochem. Biophys. Res. Commun. 2017. [CrossRef] [PubMed]

30. Bordin, L.; Zen, F.; Ion-Popa, F.; Barbetta, M.; Baggio, B.; Clari, G. Band 3 tyr-phosphorylation in normal and glucose-6-phospate dehydrogenase-deficient human erythrocytes. Mol. Membr. Biol. 2005. [CrossRef]

31. Koc, F.; Atli, G.; Menziletoglu, S.Y.; Kose, S. Antioxidant imbalance in the erythrocytes of Myotonic dystrophy Type 1 patients. Arch. Biochem. Biophys. 2020. [CrossRef] [PubMed]

32. Selby-Pham, S.N.B.; Cottrell, J.J.; Dunshea, F.R.; Ng, K.; Bennett, L.E.; Howell, K.S. Dietary phytochemicals promote health by enhancing antioxidant defence in a pig model. Nutrients 2017, 9, 758. [CrossRef]

33. Mischitelli, M.; Jemaà, M.; Almasry, M.; Faggio, C.; Lang, F. Ca 2+ Entry, Oxidative Stress, Ceramide and Suicidal Erythrocyte Death Following Diosgenin Treatment. Cell Physiol. Biochem. 2016. [CrossRef] [PubMed] 
34. Pasciu, V.; Baralla, E.; Varoni, M.V.; Demontis, M.P. Evaluation of curcuma and ginger mixture ability to prevent ROS production induced by bisphenol S: An in vitro study. Drug Chem. Toxicol. 2019. [CrossRef]

35. Baralla, E.; Demontis, M.P.; Varoni, M.V.; Pasciu, V. Bisphenol A and Bisphenol S Oxidative Effects in Sheep Red Blood Cells: An In Vitro Study. BioMed Res. Int. 2021, 2021, 1-6. [CrossRef]

36. Varoni, M.V.; Gadau, S.D.; Pasciu, V.; Baralla, E.; Serra, E.; Palomba, D.; Demontis, M.P. Investigation of the effects of Lycium barbarum polysaccharides against cadmium induced damage in testis. Exp. Mol. Pathol. 2017. [CrossRef] [PubMed]

37. Ellman, G.L. Tissue sulfhydryl groups. Arch. Biochem. Biophys. 1959. [CrossRef]

38. Ukeda, H.; Maeda, S.; Ishii, T.S.M. Spectrophotometric assay for superoxide dismutase based on tetrazolium salt $3^{\prime}-1-$ (phenylamino)-carbonyl-3, 4-tetrazolium]-bis(4-methoxy-6-nitro)benzenesulfonic acid hydrate reduction by xanthine-xanthine oxidase. Anal. Biochem. 1997, 251, 206-209. [CrossRef]

39. HB, C. A note on the molar absorptivity of reduced Ellman's reagent, 3-carboxylato-4-nitrothiophenolate. Anal. Biochem. 1973, 56, 310-311.

40. Lewinska, A.; Wnuk, M.; Slota, E.; Bartosz, G. Total anti-oxidant capacity of cell culture media. Clin. Exp. Pharmacol. Physiol. 2007. [CrossRef]

41. Spanier, A.M.; Traylor, R.D. A Rapid, Direct Chemical Assay for the Quantitative Determination of Thiobarbituric Acid Reactive Substances in Raw, Cooked, And Cooked/Stored Muscle Foods. J. Muscle Foods 1991, 165-176. [CrossRef]

42. Kang, H.P.; Scott, M.G.; Joe, B.N.; Narra, V.; Heiken, J.; Parvin, C.A. Model for predicting the impact of gadolinium on plasma calcium measured by the o-cresolphthalein method. Clin. Chem. 2004. [CrossRef]

43. Bergmeyer, H.U.; Grassl, M.; Walter, H.E. Methods of Enzymatic Analysis, 3rd ed.; Verlag Chemie: Deerfield Beach, FL, USA, 1983; Volume 2, pp. 222-223.

44. Balestri, F.; Giannecchini, M.; Sgarrella, F.; Carta, M.C.; Tozzi, M.G.; Camici, M. Purine and pyrimidine nucleosides preserve human astrocytoma cell adenylate energy charge under ischemic conditions. Neurochem. Int. 2007. [CrossRef] [PubMed]

45. Mortensen, A.; Aguilar, F.; Crebelli, R.; Di Domenico, A.; Dusemund, B.; Frutos, M.J.; Galtier, P.; Gott, D.; Gunder-Remy, U.; Leblanc, J.; et al. Revaluation of glycerol (E 422) as a food additive. EFSA J. 2017, 15. [CrossRef]

46. Zhurova, M.; Lusianti, R.E.; Higgins, A.Z.; Acker, J.P. Osmotic tolerance limits of red blood cells from umbilical cord blood. Cryobiology 2014, 69, 48-54. [CrossRef]

47. Gilmore, J.A.; Liu, J.; Gao, D.Y.; Critser, J.K. Determination of optimal cryoprotectants and procedures for their addition and removal from human spermatozoa. Hum. Reprod. 1997, 12, 112-118. [CrossRef] [PubMed]

48. Armitage, W.J.; Mazur, P. Toxic and osmotic effects of glycerol on human granulocytes. Am. J. Physiol. Physiol. 1984, 247, C382-C389. [CrossRef] [PubMed]

49. Zemlianskykh, N.G.; Babiychuk, L.A. The Production of Reactive Oxygen Species in Human Erythrocytes during Cryopreservation with Glycerol and Polyethylene Glycol. Biophys. Russ. Fed. 2019, 64, 560-567. [CrossRef]

50. Pandey, K.B.; Rizvi, S.I. Markers of oxidative stress in erythrocytes and plasma during aging in humans. Oxid. Med. Cell. Longev. 2010. [CrossRef]

51. Hernández, G.; Villanueva-Ibarra, C.A.; Maldonado-Vega, M.; López-Vanegas, N.C.; Ruiz-Cascante, C.E.; Calderón-Salinas, J.V. Participation of phospholipase-A 2 and sphingomyelinase in the molecular pathways to eryptosis induced by oxidative stress in lead-exposed workers. Toxicol. Appl. Pharmacol. 2019. [CrossRef]

52. Zemlyanskikh, N.G.; Kofanova, O.A. Modulation of human erythrocyte $\mathrm{Ca}^{2+}$-ATPase activity by glycerol: The role of calmodulin. Biochemistry 2006, 71, 900-905. [CrossRef]

53. Bigdelou, P.; Farnoud, A.M. Induction of Eryptosis in Red Blood Cells Using a Calcium Ionophore. JoVE 2020, e60659. [CrossRef]

54. Hankins, H.M.; Baldridge, R.D.; Xu, P.; Graham, T.R. Role of Flippases, Scramblases and Transfer Proteins in Phosphatidylserine Subcellular Distribution. Traffic 2015, 16, 35-47. [CrossRef]

55. Pantaleo, A.; Giribaldi, G.; Mannu, F.; Arese, P.; Turrini, F. Naturally occurring anti-band 3 antibodies and red blood cell removal under physiological and pathological conditions. Autoimmun. Rev. 2008, 7, 457-462. [CrossRef] [PubMed]

56. Bissinger, R.; Fischer, S.; Jilani, K.; Lang, F. Stimulation of erythrocyte death by phloretin. Cell. Physiol. Biochem. 2014, 34, 2256-2265. [CrossRef] [PubMed] 